\title{
Karakteristik chiffon berbahan baku tepung pisang lewat matang
}

\section{Chiffon cake characteristics from overripe banana powder}

\author{
Tjahja Muhandri ${ }^{1,2)^{*}}$, Sutrisno Koswara ${ }^{1,2)}$, Husnul Rais ${ }^{1)}$, Aminullah ${ }^{3)^{*}}$ \\ ${ }^{1}$ Departemen Ilmu dan Teknologi Pangan, Fakultas Teknologi Pertanian, Institut Pertanian Bogor \\ ${ }^{2}$ SEAFAST Center, Institut Pertanian Bogor \\ ${ }^{3}$ Departemen Teknologi Pangan dan Gizi, Fakultas Ilmu Pangan Halal, Universitas Djuanda Bogor \\ *Email korespondensi: tjahjamuhandri@apps.ipb.ac.id; aminullah@unida.ac.id
}

Informasi Artikel:

Dikirim: 18/01/2021; disetujui: 15/07/2021; diterbitkan: 25/09/2021

\begin{abstract}
Background: The X's bakery industry makes banana chiffon using fresh banana fruit as a raw material; however, fresh bananas were prone to rot. Research purposes: to apply overripe banana flour in making chiffon and study the characteristic differences with fresh banana chiffon. Method: This research consisted of making overripe banana flour using foam mat drying and making banana chiffon. The chiffon cake was made by adding $20 \mathrm{~g}, 40 \mathrm{~g}$, and $60 \mathrm{~g}$ banana flour (150g flour base) and control of $50 \mathrm{~g}$ fresh ripe bananas. The yield, color, repose angle, and moisture content of overripe banana flour were analyzed, including specific volume, chiffon color, chiffon swelling, texture profile, and moisture content in chiffon cake. A complete one-factor random design with Dunnet's analysis was used. Results and Discussion: The results showed that overripe banana flour has yellowish color with a yield of $26.23 \pm 0.45 \%$, a repose angle of $27.44 \pm 0.92$, and a moisture content of $7.97 \pm 0.43 \%$ (wet base). Statistical analysis showed that chiffon of overripe banana flour did not differ significantly at 5\% from than chiffon of fresh bananas on several parameters. They were the specific volume of the dough and moisture content and swelling, hardness, adhesiveness, elasticity, and chewing power. In addition, the chiffon's crumb section of banana flour has a lower brightness compared to fresh banana chiffon, where the top, middle, and side crusts were not significantly different. Conclusion: These results indicated that the use of banana flour could replace fresh bananas in chiffon cake.
\end{abstract}

Keywords: chiffon, overripe banana flour, physicochemical, texture profile

\begin{abstract}
ABSTRAK
Latar belakang: Industri roti PT X membuat chiffon pisang dengan bahan baku buah pisang segar, namun buah pisang segar rentan terhadap kebusukan. Tujuan penelitian: untuk mengaplikasikan tepung pisang matang dalam pembuatan chiffon serta mempelajari perbedaan karakteristik dengan chiffon pisang segar. Metode: Penelitian ini terdiri dari pembuatan tepung pisang matang menggunakan pengeringan tipe foam mat dan pembuatan chiffon pisang. Pembuatan chiffon pisang dilakukan dengan penambahan tepung pisang $20 \mathrm{~g}$, 40g dan $60 \mathrm{~g}$ (basis $150 \mathrm{~g}$ terigu) dengan kontrol yang dibuat dengan penambahan pisang matang $50 \mathrm{~g}$. Rendemen, warna, sudut repose, dan kadar air dari tepung pisang matang dianalisis, sedangkan volume spesifik, wana chiffon, daya kembang, profil tekstur, dan kadar air dianalisis pada chiffon pisang. Rancangan yang digunakan adalah rancangan acak lengkap satu faktor dengan analisis lanjut Dunnet. Hasil dan pembahasan: Tepung pisang matang memiliki warna kekuningan dengan
\end{abstract}


rendemen sebesar $26.23 \pm 0.45 \%$, sudut repose sebesar $27.44 \pm 0.92$, dan kadar air sebesar $7.97 \pm 0.43$ (\%bb). Hasil analisis statistik menunjukkan chiffon dengan penggunaan tepung pisang matang tidak berbeda secara nyata pada taraf $5 \%$ dengan chiffon dengan penggunaan pisang segar pada parameter volume spesifik adonan dan kadar air serta daya kembang, kekerasan, kelengketan, elastisitas, dan daya kunyah chiffon. Hasil analisis kecerahan warna menunjukkan bahwa bagian crumb chiffon tepung pisang memiliki kecerahan yang lebih rendah dibandingkan dengan chiffon pisang segar, sedangkan bagian crust atas, tengah, dan samping tidak berbeda nyata. Kesimpulan: Hasil ini mengindikasikan bahwa penggunaan tepung pisang dapat menggantikan buah pisang segar dalam pembuatan chiffon.

Kata kunci : chiffon, tepung pisang matang, sifat fisikokimia, profil tekstur

\section{PENDAHULUAN}

Kue atau cake merupakan makanan yang banyak disukai oleh banyak orang di seluruh dunia. Kue terbagi atas dua kategori, yaitu foam-type cake dan shortened-type cake. Shortened-type cake merupakan kue yang memiliki struktur crumb berasal dari emulsi lemak-cair yang terbentuk selama proses pembuatan adonan, seperti pound cake, yellow cake, chocolate cake. Foamstyle cake adalah kue yang struktur dan volume cake tergantung dari proses pembusaan adonan. Foam-style cake terdiri atas berbagai macam jenis, seperti chiffon, angel food, dan sponge. Chiffon memiliki karakteristik kue ringan dan lembut (Zhou, 2014). Pembuatan chiffon dapat dikombinasikan dengan berbagai macam buah, seperti buah loquat (Jung \& Bing, 2015) dan buah pisang. Selain buah, Pi et al. (2017) membuat chiffon dengan penambahan ikan. Pembuatan chiffon pisang dari buah pisang segar memiliki kelemahan, yaitu buah pisang rentan terhadap kebusukan. Proses pengolahan diperlukan untuk memperpanjang umur simpan buah, salah satu cara yang dapat dilakukan adalah dengan pembuatan tepung pisang matang.

Teknologi pembuatan tepung dari bahan dasar buah-buahan pada umumnya menggunakan teknologi spray drying, drum drying dan freeze drying. Pemanfaatan teknologi ini sulit diterapkan pada Usaha Menengah Kecil dan Mikro (UMKM) karena pemanfaatannya membutuhkan biaya yang mahal. Pengeringan busa (foam mat drying) adalah suatu proses pengeringan dengan pembuatan busa dari bahan cair yang ditambah dengan foam stabilizer dengan pengeringan pada suhu $70-75^{\circ} \mathrm{C}$, kemudian dituangkan di atas loyang atau wadah. (Purbasari, 2019). Pembuatan tepung dari buah-buahan, seperti tepung markisa pernah diteliti Susanti \& Putri (2014) dan Mulyani et al. (2014) dengan teknologi foam mat drying. Hariyadi (2019) meneliti pembuatan bubuk sari buah tomat, Wilson et al. (2012), ChauxGutiérrez et al. (2017), dan Kadam et al. (2010) mempelajari pembuatan tepung buah mangga, serta Kandasamy et al. (2019) yang membuat tepung buah pepaya dengan teknologi foam-mat drying. Pembuatan tepung pisang matang dengan teknologi foam-mat drying pernah dilakukan oleh Ekafitri et al. (2016) menggunakan jenis pisang Ambon. Pada penelitian ini, pembuatan tepung pisang matang menggunakan pisang jenis pisang Raja Bulu. Selain itu, Ali et al. (2019), Prakotmak et al. (2010), Noordia et al. (2020), dan Falade \& Okocha (2012) juga mempelajari pembuatan tepung pisang dengan menggunakan metode pengeringan tipe busa atau foam-mat.

Penggunaan tepung pisang matang sebagai bahan dasar dalam pembuatan produk chiffon memiliki keunggulan, yaitu kemudahan dalam penyimpanan bahan. Tepung terigu merupakan bahan dasar yang digunakan dalam pembuatan chiffon. Pencampuran tepung terigu dengan tepung pisang matang dapat mengurangi ketergantungan terhadap penggunaan tepung terigu. Penelitian ini bertujuan untuk mengembangkan produk chiffon dengan bahan dasar tepung pisang matang sebagai 
bahan campuran dengan tepung terigu dan mempelajari karakteristik fisik dan kimianya yang kemudian dibandingkan dengan chiffon dari pisang segar.

\section{METODE}

\section{Bahan}

Bahan untuk pembuatan tepung pisang matang adalah pisang raja bulu matang yang diperoleh dari pedagang pisang di daerah Darmaga, Bogor, putih telur, carboxy methyl cellulose (CMC) dan natrium metabisulfit. Bahan yang digunakan dalam membuat chiffon adalah tepung terigu protein rendah merek Kunci Biru, minyak goreng merek Sania, telur, gula merek Rose Brand, tepung pisang matang, santan merek Sasa, baking powder, garam, cream of Tartar.

\section{Alat}

Peralatan untuk pembuatan tepung pisang matang adalah blender (Philips, Indonesia), oven pengering tipe rak, loyang anti lengket (food grade), dan ayakan berukuran 20 mesh. Peralatan yang digunakan dalam membuat chiffon adalah mixer (Philips, Indonesia), wadah adonan, oven pemanggang, dan loyang (food grade). Peralatan analisis meliputi Chromameter CR300 Minolta dan Texture Analyzer TAXT2I Stable Micro System.

\section{Metode/ pelaksanaan}

Penelitian ini terdiri dari 3 tahapan utama, yaitu pembuatan tepung pisang lewat matang, pembuatan chiffon, dan analsis tepung dan chiffon.

\section{Pembuatan tepung pisang (Ekafitri et al.,} 2016)

Buah pisang raja bulu matang dikupas, dicuci menggunakan air bersih, dipotong dan direndam dalam larutan natrium metabisulfit $1 \%(\mathrm{w} / \mathrm{w})$ selama 2 menit, serta pembilasan menggunakan air bersih. Potongan buah pisang ditambah air dengan perbandingan pisang dan air 1:1 dan dihancurkan menggunakan blender (Philips, Indonesia) selama 1 menit, sampai terbentuk tekstur yang halus.

Pembusaan pure pisang dilakukan dengan pencampuran antara putih telur $8 \%$ (b/v pasta pisang) dan CMC $0.5 \%$ (b/v pasta pisang). Proses selanjutnya adalah adonan dikocok menggunakan mixer (selama 20 menit) dengan kecepatan maksimum. Busa pisang dituangkan ke dalam loyang anti lengket (food grade) dengan ketebalan $5 \mathrm{~mm}$ dan ditempatkan dalam oven pengering Pengeringan dilakukan pada suhu \pm 65 oC selama 5-6 jam hingga terbentuk lapisan busa kering. Tepung pisang kering dihancurkan menggunakan blender dan diayak menggunakan ayakan berukuran 20 mesh.

\section{Pembuatan chiffon}

Pembuatan chiffon diawali dengan 3 proses pencampuran, yaitu proses pencampuran putih telur, cream of tartar dan gula menggunakan mixer (Philips, Indonesia) dengan kecepatan pada no. 3 hingga terbentuk krim. Pencampuran kedua adalah proses pencampuran kuning telur, gula dan santan dengan mixer pada wadah yang berbeda. Pencampuran ketiga adalah proses pencampuran kering (dry mixing) dilakukan pada bahan tepung terigu, tepung pisang matang, baking powder dan garam dengan mixer pada wadah yang berbeda.

Proses selanjutnya adalah proses pencampuran antara hasil pencampuran pertama dan pencampuran kering dengan mixer. Minyak goreng dimasukkan ke dalam adonan dan dicampurkan kembali dengan mixer. Adonan krim dituangkan ke dalam wadah adonan yang telah tercampur. Proses selanjutnya adalah proses pencampuran dengan teknik pencampuran melipat dengan sendok pengaduk. Adonan dituangkan ke dalam loyang dan dipanggang dalam oven yang telah diatur suhu dan waktunya, yaitu setting suhu atas sebesar $165^{\circ} \mathrm{C}$ dan setting suhu bawah sebesar $170^{\circ} \mathrm{C}$ selama 50 menit. Chiffon dikeluarkan dari oven dan didinginkan pada suhu kamar. Terdapat 4 jenis chiffon yang dibuat, yaitu chiffon 1 (standar), chiffon 2 (penggunaan tepung pisang matang sebesar $20 \mathrm{~g}$ ), chiffon 3 (penggunaan tepung pisang matang sebesar $40 \mathrm{~g}$ ), chiffon 4 (penggunaan tepung pisang matang sebesar 60g), Komposisi bahan pembuat chiffon dapat dilihat pada Tabel 1. 
Tabel 1. Komposisi bahan pembuat chiffon

\begin{tabular}{lcccc}
\hline \multirow{2}{*}{ Bahan } & \multicolumn{4}{c}{ Formula Chiffon } \\
\cline { 2 - 5 } & 1 & 2 & 3 & 4 \\
\hline Terigu protein sedang (gram) & 150 & 150 & 150 & 150 \\
Tepung Pisang (gram) & 0 & 20 & 40 & 60 \\
Pisang (gram) & 50 & 0 & 0 & 0 \\
Kuning Telur (gram) & 100 & 100 & 100 & 100 \\
Putih Telur (gram) & 190 & 190 & 190 & 190 \\
Gula Pasir 1 (gram) & 100 & 100 & 100 & 100 \\
Gula Pasir 2 (gram) & 95 & 95 & 95 & 95 \\
Santan (gram) & 75 & 75 & 75 & 75 \\
Baking Powder (gram) & 4 & 4 & 4 & 4 \\
Garam (gram) & 3 & 3 & 3 & 3 \\
Minyak goreng (gram) & 83 & 83 & 83 & 83 \\
\hline
\end{tabular}

\section{Tahap analisis tepung pisang matang}

Rendemen (Ekafitri et al., 2016)

Penghitungan rendemen produk didapatkan melalui perbandingan antara bobot tepung pisang matang dengan bobot daging buah pisang sebelum diproses. Penghitungan rendemen produk didapatkan melalui persamaan.

$$
\begin{aligned}
\text { Rendemen }= & \frac{\text { Bobot tepung pisang }(\mathrm{g})}{\text { Bobot daging pisang }(\mathrm{g})} \\
& \times 100 \%
\end{aligned}
$$

\section{Analisis warna}

Sejumlah sampel ditempatkan pada cawan petri. Sampel akan dianalisi dengan cara menembakkan sinar melalui alat chromameter. Hasil analisis warna yang didapatkan sesuai dengan sistem warna Hunter $L^{*}, a^{*}, b^{*}$. Notasi L menunjukkan kecerahan dan mempunyai nilai 0 (hitam) sampai 100 (putih). Peningkatan nilai $\mathrm{L}$ menghasilkan sampel berwarna cerah. Notasi a menunjukkan warna kromatik campuran merah-hijau dengan nilai +a dari 0 sampai +100 untuk warna merah dan nilai -a dari 0 sampai -80 untuk warna hijau. Notasi b menyatakan warna kromatik campuran biru-kuning dengan nilai +b dari 0 sampai +70 untuk warna kuning dan nilai -b dari 0 sampai -80 untuk warna biru.

Sudut repose (Priastuti et al., 2016)

Sudut curah atau sudut repose merupakan sudut yang terbentuk antara bidang datar dan sisi miring curahan jika tepung atau biji-bijian dituangkan di atas bidang datar. Jarak lubang corong dengan bidang datar sebesar $200 \mathrm{~mm}$.
Kadar air tepung pisang matang (AOAC, 1995)

Analisis kadar air dengan metode oven diawali dengan pengeringan cawan kosong dalam oven selama 15 menit, pendinginan cawan kering dalam desikator selama 10 menit, serta penimbangan cawan (W2). Sampel ditimbang sebanyak 2-5g (W) dan dimasukkan ke dalam cawan serta dikeringkan dalam oven pada suhu 100105oC selama 6 jam. Tahap akhir adalah pendinginan cawan ke dalam desikator selama 15 menit dan penimbangan cawan hingga mencapai berat konstan (W1). Perhitungan kadar air dapat dilakukan melalui persamaan sebagai berikut:

$$
\text { Kadar air }(\% \text { bb })=\frac{\mathrm{W}-(\mathrm{W} 1-\mathrm{W} 2)}{\mathrm{W}} \times 100 \%
$$

\section{Tahap analisis produk chiffon}

\section{Volume spesifik adonan dan chiffon (AACC, 1983) \\ Pengukuran volume spesifik adonan} dilakukan dengan perbandingan berat adonan sebelum dimasukkan loyang dengan volume adonan dengan cara mengukur volume loyang. Pengukuran volume spesifik chiffon dilakukan dengan cara mengukur chiffon ke dalam wadah yang telah diketahui volumenya. Wadah yang berisikan chiffon tersebut diisikan dengan kacang hijau dan diratakan dengan sendok serta dicatat volumenya. Chiffon dikeluarkan dari dalam wadah dan volume akhir dicatat. Volume chiffon dihasilkan dari selisih antara volume akhir dengan volume awal dalam wadah Tahapan selanjutnya adalah pembandingan 
volume chiffon dengan berat chiffon yang dihasilkan. Rumus pengukuran volume spesifik adonan dan chiffon disajikan di bawah ini:

Volume spesifik adonan $\left(\mathrm{cm}^{3} / \mathrm{g}\right)$

$$
=\frac{\text { Volume adonan chiffon }}{\text { Berat adonan }}
$$

Volume spesifik chiffon $\left(\mathrm{cm}^{3} / \mathrm{g}\right)$

$$
=\frac{\text { Volume chiffon }}{\text { Berat chiffon }}
$$

Warna chiffon (Yunieta \& Sutrisno, 2018)

Sejumlah sampel ditempatkan pada cawan petri. Sampel akan dianalisi dengan cara menembakkan sinar melalui alat chromameter. Hasil analisis warna yang didapatkan sesuai dengan sistem warna Hunter $\mathrm{L}^{*}, \mathrm{a}^{*}, \mathrm{~b}^{*}$. Pengukuran warna chiffon dilakukan pada bagian crust atas, bawah, samping dan crumb. Notasi L menunjukkan kecerahan dan mempunyai nilai 0 (hitam) sampai 100 (putih). Peningkatan nilai $\mathrm{L}$ akan menghasilkan sampel berwarna cerah. Notasi a menyatakan warna kromatik campuran merah-hijau dengan nilai +a dari 0 sampai +100 untuk warna merah dan nilai -a dari 0 sampai -80 untuk warna hijau. Notasi b menyatakan warna kromatik campuran biru-kuning dengan nilai $+b$ dari 0 sampai +70 untuk warna kuning dan nilai -b dari 0 sampai -80 untuk warna biru.

Daya kembang chiffon (Yunieta \& Sutrisno, 2018)

Daya kembang chiffon diukur dengan membandingkan volume akhir chiffon setelah matang dan volume awal adonan. Pembuatan chiffon menggunakan loyang berbentuk lingkaran dengan diameter loyang sebesar $22 \mathrm{~cm}$. Rasio pengembangan volume chiffon didapatkan dengan rumus:

Rasio Pengembangan Volume Chiffon

$$
=\frac{\text { volume Chiffon }}{\text { volume Adonan }}
$$

Profil tekstur chiffon (Chaiya \& Pongsawatmanit, 2011)

Analisis profil tekstur chiffon dengan Texture Analyzer TA-XT2I Stable Micro System. Uji yang digunakan adalah TPA (Texture Profile Analysis) dengan Pre-Test
Speed $2.0 \mathrm{~mm} / \mathrm{s}$, Test Speed $1.0 \mathrm{~mm} / \mathrm{s}$, PostTest Speed $2.0 \mathrm{~mm} / \mathrm{s}$, Distance $50.0 \%$, Time $5.00 \mathrm{~s}$, triger force $5 \mathrm{~g}$ dan trigger type auto. Parameter yang diukur antara lain kekerasan (hardness), elatisitas (springiness), daya kohesif (cohesiveness), kelengketan (gumminess), daya kunyah (chewiness). Kekerasan ditentukan dari gaya maksimum pada tekanan pertama. Daya kohesif dihitung dari luasan di bawah kurva pada tekanan kedua dibandingkan dengan luasan di bawah kurva pada tekanan pertama. Elastisitas dihitung dari jarak yang ditempuh produk pada tekanan kedua sehingga tercapai nilai gaya maksimum dibandingkan dengan jarak yang ditempuh produk pada tekanan pertama yang mencapai nilai maksimum. Kelengketan dihitung dari hasil perkalian nilai kekerasan dengan daya kohesif. Daya kunyah dihitung dari hasil perkalian nilai kelengketan dengan elastisitas.

Analisis kadar air chiffon (AOAC, 1995)

Analisis kadar air dengan metode oven diawali dengan pengeringan cawan kosong dalam oven selama 15 menit, pendinginan cawan kering dalam desikator selama 10 menit, serta penimbangan cawan (W2). Sampel ditimbang sebanyak 2-5 g (W) dan dimasukkan ke dalam cawan serta dikeringkan dalam oven pada suhu 100$105^{\circ} \mathrm{C}$ selama 6 jam. Tahap akhir adalah pendinginan cawan ke dalam desikator selama 15 menit dan penimbangan cawan hingga mencapai berat yang konstan (W1). Perhitungan kadar air dapat dilakukan melalui persamaan sebagai berikut:

$$
\text { Kadar air }(\% \mathrm{bb})=\frac{\mathrm{w}-(\mathrm{W} 1-\mathrm{W} 2)}{\mathrm{W}} \times 100 \%
$$

\section{Prosedur analisis data}

Analisis data secara statistik dilakukan menggunakan program SPSS 16 dengan taraf kepercayaan $95 \% \quad(\mathrm{p}<0.05)$, yaitu dengan analisis ragam (ANOVA) untuk melihat pengaruh faktor terhadap parameter yang diuji. Analisis dilanjutkan dengan uji Dunnett untuk melihat perbedaan satu sampel atau lebih dengan kontrol (standar).

HASIL DAN PEMBAHASAN 


\section{Karakteristik tepung pisang matang}

\section{Rendemen tepung pisang terhadap daging buah pisang}

Rendemen tepung pisang matang yang dihasilkan sebesar 26.23 $\pm 0.45 \%$. Hasil rendemen yang didapatkan lebih tinggi dibandingkan hasil pengukuran yang dilakukan oleh Ekafitri et al. (2016), yaitu sebesar $18.42 \%$. Perbedaan jumlah rendemen dapat disebabkan oleh total padatan dan kadar air yang terkandung dalam buah pisang Raja Bulu matang, yaitu sebesar $39.3{ }^{\circ}$ Brix dan $60.7 \%$, berturut-turut (Hidayat, 2010). Jumlah rendemen tepung pisang juga dipengaruhi oleh proses pembuatan tepung pisang, yaitu perendaman buah pisang matang dalam larutan $\mathrm{Na}$ metabisulfit menyebabkan terdapat komponen karbohidrat dan protein yang larut (Hidayat, 2010).

\section{Warna}

Hasil analisis menunjukkan tingkat kecerahan (Nilai L) sebesar 34.57 \pm 2.10 dengan nilai $\mathrm{a}$ dan $\mathrm{b}$ tepung pisang matang masing-masing sebesar $3.72 \pm 0.49$ dan $8.60 \pm 0.82$. Nilai a positif menunjukkan bahwa tepung pisang yang dihasilkan berwarna merah karena daging buah mengalami perubahan warna dari warna putih dengan kandungan pati yang tinggi menjadi warna kuning muda yang dicirikan juga dengan berubahnya warna kulit buah selama proses pematangan buah pisang (Shahir \& Visvanathan, 2014). Nilai b positif menunjukkan bahwa tepung pisang matang yang dihasilkan mengandung warna kuning karena kandungan karbohidrat dan protein berpengaruh terhadap pencokelatan nonenzimatik (Jamin \& Flores, 1998).

Warna tepung pisang matang dipengaruhi oleh pigmen dalam buah pisang yang digunakan, lamanya proses pengeringan, dan suhu pengeringan. Penggunaan suhu tinggi dan waktu pengeringan yang lama dapat menyebabkan tepung pisang matang mengalami degradasi warna. RH lingkungan selama proses penyimpanan tepung pisang matang dapat mempengaruhi kualitas tepung yang dihasilkan karena kandungan gula dalam tepung yang dapat mengikat air. Selain itu, warna tepung pisang dapat dipengaruhi oleh reaksi pencokelatan karena aktifitas enzim (enzymatic browning) dan reaksi pencokelatan karena aktifitas non-enzimatis (non-enzymatic browning) (Hidayat, 2010).

Enzymatic browning terjadi karena terdapat aktifitas enzim fenolase atau polifenolase yang dapat mengkatalisis reaksi oksidasi senyawa fenol dan polifenol menjadi keton. Reaksi lanjutan tersebut akan menghasilkan senyawa yang dapat membentuk berwarna cokelat. Nonenzymatic browning dibedakan atas tiga macam reaksi yaitu reaksi maillard, pencokelatan akibat vitamin $\mathrm{C}$ dan karamelisasi. Karamelisasi terbentuk akibat bahan pangan berkadar gula tinggi dipanaskan pada suhu tinggi yang melebihi titik lebur gula. Hal tersebut mengakibatkan dehidarsi gula dan terbentuklah senyawa aldehid aktif yang menyebabkan warna cokelat. Reaksi maillard terjadi ketika gugus gula pereduksi bereaksi dengan gugus amino pada protein. Akhir dari reaksi maillard adalah pembentukan pigmen melanoidin yang dapat membentuk warna cokelat. Pencokelatan akibat vitamin $\mathrm{C}$ terjadi akibat adanya perubahan secara kimia vitamin $\mathrm{C}$ (asam askorbat) menjadi senyawa fulfural dan berpolimerasi sehingga membentuk warna cokelat (Hidayat, 2010).

\section{Sudut repose}

Sudut Repose adalah sifat fisik dalam suatu bahan berbentuk granula ketika dituangkan dalam suatu permukaan horizontal akan membentuk suatu gundukan berbentuk kerucut. Sudut yang terbentuk antara sisi miring gundukan dengan permukaan horizontal disebut sebagai sudut repose (Pangaribuan et al., 2016). Sudut repose dipengaruhi oleh ukuran partikel, bentuk karakteristik permukaan partikel, kandungan air, berat jenis dan kerapatan tumpukan. Bahan dengan nilai sudut repose yang rendah akan menunjukkan sifat alir yang baik karena sudut repose berhubungan dengan gaya kohesi partikel bahan. Hasil analisis sudut repose menunjukkan bahwa sudut repose tepung pisang matang yang 
dihasilkan sebesar 27.44 \pm 0.92 .

\section{Kadar air}

Kandungan air dalam bahan pangan merupakan hal penting untuk diketahui karena air dapat mempengaruhi kenampakan, warna, tekstur dan cita rasa dari bahan pangan tersebut. Kandungan air juga menentukan tingkat penerimaan pangan, daya tahan pangan dan kesegaran bahan pangan. Kadar air tepung pisang matang ditentukan oleh kandungan awal buah pisang, lama proses pengeringan, dan suhu pengeringan. Kadar air tepung pisang matang yang dihasilkan sebesar $7.97 \pm 0.43$ (\%bb). Berdasarkan ketentuan SNI 01-38411995, kadar air maksimum yang dimiliki tepung pisang adalah $5 \%$ (BSN, 1995). Nilai kadar air yang melebihi ketentuan SNI dapat disebabkan oleh ikatan air dengan gula sederhana yang terkandung dalam tepung pisang matang selama proses penyimpanan produk karena tepung pisang matang yang bersifat higroskopis. Kadar air yang tinggi dapat disebabkan oleh pengembangan busa yang rendah sehingga terjadi penurunan nilai luas permukaan bahan dan kontak antara bahan dengan udara pengering menjadi berkurang. Peristiwa tersebut menyebabkan proses pengeringan tidak efektif.

\section{Karakteristik chiffon}

\section{Volume spesifik adonan dan chiffon}

Pengukuran volume spesifik adonan dilakukan dengan cara membandingkan antara berat adonan sebelum dimasukkan ke dalam loyang dengan volume adonan tersebut dalam gelas ukur. Pengukuran volume spesifik chiffon dilakukan dengan membandingkan berat chiffon dengan volume chiffon di mana dapat dilihat pada Tabel 2.

Tabel 2. Nilai volume spesifik adonan dan chiffon

\begin{tabular}{ccc}
\hline $\begin{array}{c}\text { Konsentrasi tepung pisang matang } \\
(\mathrm{g})\end{array}$ & $\begin{array}{c}\text { Volume spesifik adonan } \\
(\mathrm{ml} / \mathrm{g})\end{array}$ & Volume spesifik chiffon $(\mathrm{ml} / \mathrm{g})$ \\
\hline 0 (Standar) & $1.53 \pm 0.18^{\mathrm{a}}$ & $2.62 \pm 0.52^{\mathrm{a}}$ \\
20 & $1.37 \pm 0.47^{\mathrm{a}}$ & $2.55 \pm 0.10^{\mathrm{a}}$ \\
40 & $1.35 \pm 0.18^{\mathrm{a}}$ & $2.50 \pm 0.05^{\mathrm{a}}$ \\
60 & $1.31 \pm 0.30^{\mathrm{a}}$ & $2.42 \pm 0.01^{\mathrm{a}}$ \\
\hline
\end{tabular}

Keterangan: Angka superscript yang berbeda pada kolom yang sama menunjukkan perbedaan yang signifikan $(\alpha=5 \%)$.

Tabel 2 menunjukkan bahwa penggunaan tepung pisang tidak berbeda secara signifikan dari standar (buah pisang segar) berdasarkan hasil uji lanjut Dunnett. Volume spesifik chiffon berkaitan dengan tingkat viskositas adonan. Viskositas adonan harus tepat agar dapat mengumpulkan udara yang dihasilkan oleh baking powder selama proses pemanggangan. Peningkatan viskositas adonan dengan penambahan serat yang berasal dari tepung pisang matang membantu mengumpulkan udara dalam chiffon sehingga terjadi peningkatan volume chiffon. Tepung pisang mengandung serat sebesar 6.59 g/100 g serat (Segundo et al., 2017).

Parameter yang mempengaruhi karakteristik adonan adalah tipe dan jumlah bahan yang digunakan, tingkatan udara yang terdapat pada adonan (level of air incorporation) dan suhu. Air incorporation dapat dipengaruhi oleh waktu dan kecepatan mixing, design mixer dan tegangan permukaan pada adonan chiffon.

\section{Warna chiffon}

Pengukuran warna chiffon dilakukan dengan chromameter. Data pada Tabel 3 menunjukkan nilai L yang beragam. Hasil analisis statistik menunjukkan bahwa kecerahan chiffon tepung pisang pada bagian crust atas, bawah, dan samping tidak berbeda secara nyata pada taraf $5 \%$ dengan chiffon standar, akan tetapi berbeda nyata pada bagian crumb chiffon. Hal ini menunjukkan bahwa penggunaaan tepung pisang matang menyebabkan warna chiffon cendrung menjadi lebih 
gelap terutama pada bagian crumb chiffon karena warna dari tepung pisang matang yang digunakan. Tepung pisang matang yang dibuat dari buah pisang yang sudah matang akan mengalami perubahan warna ketika dikeringkan akibat pengaruh reaksi browning.

Tabel 3. Nilai L, a, dan b pada chiffon dengan menggunakan chromameter

\begin{tabular}{lcccc}
\hline Bagian Chiffon & $\begin{array}{c}\text { Konsentrasi tepung } \\
\text { pisang matang }(\mathrm{g})\end{array}$ & $\mathrm{L}$ & $\mathrm{a}$ & $\mathrm{b}$ \\
\hline \multirow{4}{*}{ Crust Bawah } & 0 & $39.40 \pm 2.84^{\mathrm{a}}$ & $14.84 \pm 0.90^{\mathrm{a}}$ & $18.34 \pm 1.31^{\mathrm{a}}$ \\
& 20 & $37.91 \pm 3.07^{\mathrm{a}}$ & $13.8 \pm 0.53^{\mathrm{a}}$ & $17.82 \pm 1.49^{\mathrm{a}}$ \\
& 40 & $37.40 \pm 2.81^{\mathrm{a}}$ & $12.28 \pm 0.39^{\mathrm{a}}$ & $12.42 \pm 0.34^{\mathrm{a}}$ \\
& 60 & $36.74 \pm 0.68^{\mathrm{a}}$ & $11.51 \pm 0.38^{\mathrm{a}}$ & $9.43 \pm 1.64^{\mathrm{a}}$ \\
\hline \multirow{4}{*}{ Crumb } & 0 & $66.91 \pm 2.55^{\mathrm{a}}$ & $-2.69 \pm 0.21^{\mathrm{a}}$ & $23.14 \pm 1.13^{\mathrm{a}}$ \\
& 20 & $57.54 \pm 0.45^{\mathrm{b}}$ & $0.55 \pm 0.20^{\mathrm{b}}$ & $17.12 \pm 0.12^{\mathrm{b}}$ \\
& 40 & $57.06 \pm 0.57^{\mathrm{b}}$ & $1.15 \pm 0.43^{\mathrm{b}}$ & $14.94 \pm 0.38^{\mathrm{b}}$ \\
& 60 & $53.75 \pm 2.23^{\mathrm{b}}$ & $3.20 \pm 0.76^{\mathrm{b}}$ & $10.50 \pm 0.51^{\mathrm{b}}$ \\
\hline & 0 & $44.21 \pm 2.55^{\mathrm{a}}$ & $15.31 \pm 0.48^{\mathrm{a}}$ & $21.39 \pm 1.71^{\mathrm{a}}$ \\
& 20 & $39.26 \pm 0.52^{\mathrm{a}}$ & $13.83 \pm 0.83^{\mathrm{a}}$ & $18.10 \pm 0.46^{\mathrm{a}}$ \\
& 40 & $38.80 \pm 0.76^{\mathrm{a}}$ & $12.28 \pm 0.37^{\mathrm{a}}$ & $11.94 \pm 1.38^{\mathrm{a}}$ \\
& 60 & $39.45 \pm 0.45^{\mathrm{a}}$ & $11.41 \pm 0.48^{\mathrm{a}}$ & $10.94 \pm 1.33^{\mathrm{a}}$ \\
\hline \multirow{4}{*}{ Crust Samping Atas } & 0 & $40.12 \pm 0.48^{\mathrm{a}}$ & $15.52 \pm 0.28^{\mathrm{a}}$ & $19.18 \pm 0.43^{\mathrm{a}}$ \\
& 20 & $36.41 \pm 1.27^{\mathrm{a}}$ & $12.11 \pm 0.79^{\mathrm{a}}$ & $15.41 \pm 1.15^{\mathrm{a}}$ \\
& 40 & $41.66 \pm 1.81^{\mathrm{a}}$ & $10.53 \pm 0.08^{\mathrm{a}}$ & $10.94 \pm 0.87^{\mathrm{a}}$ \\
& 60 & $39.43 \pm 0.64^{\mathrm{a}}$ & $10.72 \pm 0.67^{\mathrm{a}}$ & $10.02 \pm 1.33^{\mathrm{a}}$ \\
\hline
\end{tabular}

Keterangan: huruf supercript yang sama pada setiap bagian chiffon menunjukkan tidak berbeda nyata pada taraf $5 \%$

Warna crust chiffon dapat disebabkan oleh reaksi maillard yang disebabkan oleh reaksi antara gula pereduksi dan asam amino bebas. Hasil reaksi akan menghasilkan pigmen cokelat (Akesowan, 2010). Reaksi karamelisasi yang terbentuk akibat gula yang diberikan suhu tinggi juga dapat mempengaruhi warna chiffon. Tabel 3 juga menunjukkan nilai a bagian crumb chiffon pada perlakuan tepung pisang matang memiliki hasil yang berbeda dengan standar. Nilai a bagian crumb chiffon standar menunjukkan warna chiffon yang berwarna hijau, tetapi nilai a perlakuan tepung pisang matang berwarna merah. Warna chiffon yang dihasilkan dapat dilihat pada Gambar 1.
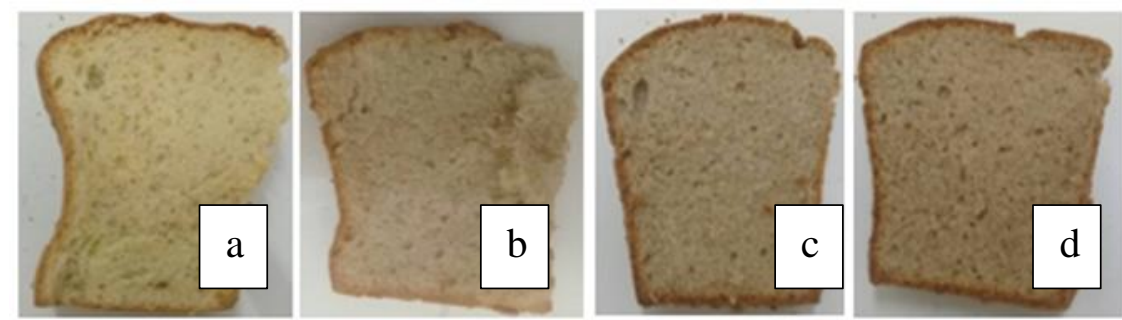

Gambar 1. Warna chiffon standar (a), chiffon $20 \mathrm{~g}$ tepung pisang matang (b), chiffon $40 \mathrm{~g}$ tepung pisang matang $(\mathrm{c})$, chiffon $60 \mathrm{~g}$ tepung pisang matang $(\mathrm{d})$

\section{Daya kembang chiffon}

Pengukuran daya kembang chiffon dilakukan dengan mengukur volume adonan dan volume chiffon. Hasil pengukuran daya kembang chiffon yang dibuat dari tepung pisang matang disajikan pada Tabel 4. 
Tabel 4. Nilai daya kembang chiffon

\begin{tabular}{cc}
\hline Konsentrasi tepung pisang matang $(\mathrm{g})$ & Daya kembang \\
\hline 0 (standar) & $1.23 \pm 0.05^{\mathrm{a}}$ \\
20 & $1.32 \pm 0.05^{\mathrm{a}}$ \\
40 & $1.32 \pm 0.10^{\mathrm{a}}$ \\
60 & $1.33 \pm 0.07^{\mathrm{a}}$ \\
\hline
\end{tabular}

Keterangan: Angka superscript yang berbeda pada kolom yang sama menunjukkan perbedaan yang signifikan $(\alpha=5 \%)$.

Hasil uji lanjut Dunnet pada Tabel 4 menunjukkan bahwa daya kembang chiffon dengan penambahan tepung pisang matang tidak berbeda secara nyata dengan daya kembang chiffon standar atau chiffon yang ditambah buah pisang matang segar pada taraf 5\%. Pengembangan chiffon dipengaruhi oleh pembentukan sel udara (air cell) dalam adonan. Air cell terdiri dari ruang terbuka yang dikelilingi oleh dinding sel elastis yang terbuat dari protein, seperti gluten dan albumin telur. Mekanisme air cell dalam mempengaruhi pengembangan chiffon, yaitu gas yang dihasilkan dari leavening agent dikumpulkan dalam sel udara. Menurut Godefroidt et al. (2019), proses pemanggangan pada kue menyebabkan kue kehilangan kadar air yang kemudian diikuti dengan dimulainya peningkatan volume kue. Keadaan akhir akan memerangkap sel udara pada matriks protein dan pati.

Pembuatan chiffon dengan penambahan tepung pisang menyebabkan peningkatan kandungan gula dalam adonan sehingga dapat memperpanjang suhu gelatinisasi pati dan koagulasi protein selama proses pemanggangan. Peningkatan suhu tersebut menyebabkan gluten lebih merenggang selama pemanggangan sehinga terjadi peningkatan volume chiffon (Zhou, 2014). Tepung pisang memiliki kandungan gula sederhana (glukosa, fruktosa, sukrosa dan maltosa) sebesar $61.06 \mathrm{~g} / 100 \mathrm{~g}$ (Segundo et al., 2017). Faktor lain yang mempengaruhi daya kembang chiffon yaitu jenis loyang, waktu dan temperature pemanggangan. Loyang yang berwarna gelap dan mempunyai permukaan kasar dapat menyerap panas lebih cepat sehingga menghasilkan waktu pemanggangan yang lebih cepat, chiffon yang lebih besar, tekstur chiffon lembut.

Waktu penuangan adonan dan pemanasan oven mempengaruhi kualitas chiffon. Adonan yang terlalu lama didiamkan di dalam loyang sebelum masuk ke dalam oven akan menyebabkan penguapan karbodioksida dan udara sehingga terjadi penurunan volume chiffon dan peningkatan remah kasar. Pemanasan dalam oven selama pemanggangan berpengaruh terhadap volume dan pelepasan udara, uap air, dan karbohidrat sehingga dapat mempengaruhi struktur chiffon melalui koagulasi protein dan gelatinisasi pati. Penurunan volume chiffon juga dapat terjadi ketika oven dibuka selama pemanggangan.

\section{Profil tekstur}

Penggunaan tepung pisang matang mempengaruhi karakteristik tekstur chiffon. Karakteristik tekstur yang dianalisis meliputi kekerasan, elastisitas, daya kohesif, kelengketan dan daya kunyah. Hasil pengukuran profil tekstur chiffon yang dibuat dari buah pisang segar (standar) dan tepung pisang matang disajikan pada Tabel 5. 
Tabel 5. Profil tekstur chiffon tepung pisang

\begin{tabular}{lcccc}
\hline \multirow{2}{*}{ Profil tekstur } & \multicolumn{4}{c}{ Konsentrasi tepung pisang matang $(\mathrm{g})$} \\
\cline { 2 - 5 } & 0 (Standar) & 20 & 40 & 60 \\
\hline Kekerasan (gF) & $449.20 \pm 33.7^{\mathrm{a}}$ & $315.08 \pm 19.3^{\mathrm{a}}$ & $346.83 \pm 86.7^{\mathrm{a}}$ & $386.50 \pm 74.4^{\mathrm{a}}$ \\
Elastisitas (rasio) & $0.82 \pm 0.01^{\mathrm{a}}$ & $0.84 \pm 0.03^{\mathrm{a}}$ & $0.86 \pm 0.04^{\mathrm{a}}$ & $0.87 \pm 0.01^{\mathrm{a}}$ \\
Daya Kohesif (rasio) & $0.62 \pm 0.04^{\mathrm{a}}$ & $0.60 \pm 0.02^{\mathrm{a}}$ & $0.61 \pm 0.02^{\mathrm{a}}$ & $0.61 \pm 0.02^{\mathrm{a}}$ \\
Kelengketan $(\mathrm{gF})$ & $0.51 \pm 0.04^{\mathrm{a}}$ & $0.50 \pm 0.03^{\mathrm{a}}$ & $0.53 \pm 0.03^{\mathrm{a}}$ & $0.53 \pm 0.02^{\mathrm{a}}$ \\
Daya Kunyah $(\mathrm{gF})$ & $4144.10 \pm 0.04^{\mathrm{a}}$ & $4243.97 \pm 0.04^{\mathrm{a}}$ & $4525,67 \pm 0.05^{\mathrm{a}}$ & $4652.98 \pm 0.02^{\mathrm{a}}$ \\
\hline
\end{tabular}

Keterangan: Angka superscript yang berbeda pada baris yang sama menunjukkan perbedaan yang signifikan ( $\alpha=5 \%)$.

Hasil analisis uji Dunnet pada taraf 5\% menunjukkan bahwa penambahan tepung pisang matang dalam pembuatan chiffon tidak berbeda secara nyata dengan chiffon standar. Akan tetapi, nilai rata-rata kekerasan chiffon dengan penambahan tepung pisang masih lebih rendah dibandingkan standar. Hal tersebut dapat disebabkan oleh kandungan air yang terkandung pada chiffon. Selain itu, penambahan tepung pisang matang menyebabkan nilai rata-rata kekerasan chiffon cenderung lebih rendah karena tepung pisang matang mengandung kandungan gula yang tinggi sehingga chiffon memiliki sifat higroskopis yang tinggi. Data analisis profil tekstur juga menunjukkan bahwa parameter elastisitas, daya kohesif, kelengketan chiffon, dan daya kunyah dengan penambahan tepung pisang matang tidak berbeda secara nyata dengan chiffon standar pada taraf 5\%.

\section{Kadar air}

Kadar air sangat mempengaruhi kualitas chiffon. Pengukuran kadar air dilakukan dengan cara mengeringkan sampel chiffon bedasarkan jumlah penambahan tepung pisang. Hasil pengukuran kadar air disajikan pada Tabel 6 .

Tabel 6. Hasil analisis kadar air chiffon metode oven

\begin{tabular}{cc}
\hline Konsentrasi tepung pisang matang $(\mathrm{g})$ & Kadar air $(\% \mathrm{bb})$ \\
\hline 0 (Standar) & $31.48 \pm 0.12^{\mathrm{a}}$ \\
20 & $29.88 \pm 0.20^{\mathrm{b}}$ \\
40 & $28.72 \pm 0.37^{\mathrm{b}}$ \\
60 & $27.73 \pm 0.10^{\mathrm{b}}$ \\
\hline
\end{tabular}

Keterangan: Angka superscript yang berbeda pada baris yang sama menunjukkan perbedaan yang signifikan $(\alpha=5 \%)$.

Hasil uji lanjut Dunnett pada Tabel 6 menunjukkan penambahan tepung pisang sebanyak $20 \mathrm{~g}, 40 \mathrm{~g}, 60 \mathrm{~g}$ berbeda dari standar. Selain itu, peningkatan kadar tepung pisang yang ditambahkan dapat menurunkan kadar air chiffon. Penambahan tepung pisang matang akan menurunkan kadar air chiffon karena sifat higroskopis gula yang terkandung dalam tepung pisang matang.

\section{KESIMPULAN}

Chiffon dengan penggunaan tepung pisang matang memiliki karakteristik fisik seperti volume spesifik adonan, daya kembang, dan profil tekstur yang tidak berbeda secara nyata dibandingkan dengan chiffon pisang segar. Sedangkan chiffon tepung pisang memiliki kadar air yang lebih rendah. Selain itu, penggunaan tepung pisang matang dapat menurunkan tingkat kecerahan pada bagian crumb chiffon, akan tetapi pada bagian lainnya seperti crust bagian atas, bawah, dan samping tidak berbeda secara nyata dibandingkan dengan chiffon pisang segar. Hasil ini mengindikasikan bahwa penggunaan tepung pisang dapat menggantikan buah pisang segar dalam pembuatan chiffon.

\section{DAFTAR PUSTAKA}

AACC. (1983). Approved Method of the 8th Edition. St Paul: American Association 
Cereal Chemists.

Akesowan, A. (2010). Effect of konjac flour incorporated with soy protein isolate on quality characteristics of reducedfat chiffon cakes. African Journal of Biotechnology, 9(28), 4386-4391. https://doi.org/10.5897/AJB10.1671

Ali, L., Shujaat, N., Musarrat Gilani, S., Ur Rehman, H., Khan, F., Noor, H., Ali Khan, N., Ayaz, U., Ghani, U., Sadia, H., Raza, S., Malik, K., Ali, U., Khan, M., Tul Munthah, S., Ullah, S., Noreen, F., \& Jammu, A. (2019). Foam mat drying of banana (Musa acuminate) pulp. Biological Forum-An International Journal, 11(1), 280-283.

AOAC. (1995). Official Methods of Analysis of the Association of Official Analytical Chemist, 18th Edition. Gaithersburg: Association of Official Analitical Chemist.

BSN. (1995). SNI 01-3841-1995 tentang Tepung Pisang. Jakarta: Badan Standardisasi Nasional.

Chaiya, B., \& Pongsawatmanit, R. (2011). Quality of batter and sponge cake prepared from wheat-tapioca flour blends. Kasetsart Journal - Natural Science, 45(2), 305-313.

Chaux-Gutiérrez, A. M., Santos, A. B., Granda-Restrepo, D. M., \& Mauro, M. A. (2017). Foam mat drying of mango: effect of processing parameters on the drying kinetic and product quality. Drying Technology, 35(5), 631-641. https://doi.org/10.1080/07373937.2016 .1201486

Ekafitri, R., Surahman, D. D., \& Afifah, N. (2016). Pengaruh penambahan dekstrin dan albumen telur (putih telur) terhadap mutu tepung pisang matang. Jurnal Litbang Industri, 6(1), 13-24. https://doi.org/10.24960/jli.v6i1.1062.1 3-24

Falade, K. O., \& Okocha, J. O. (2012). Foam-Mat Drying of Plantain and Cooking Banana (Musa spp.). Food Bioprocess Technol, 5, 1173-1180. https://doi.org/10.1007/s11947-0100354-0
Godefroidt, T., Ooms, N., Pareyt, B., Brijs, K., \& Delcour, J. A. (2019). Ingredient functionality during foam-type cake making: a review. Comprehensive Reviews in Food Science and Food Safety, 18(5), 1550-1562. https://doi.org/10.1111/15414337.12488

Hariyadi, T. (2019). Aplikasi metoda foammat drying pada proses pengeringan tomat menggunakan tray dryer. Prosiding Industrial Research Workshop and National Seminar. Bandung: Politeknik Negeri Bandung. https://doi.org/https://doi.org/10.35313 /irwns.v10i1.1396

Hidayat, R. (2010). Mempelajari pembuatan tepung pisang raja bulu kaya $\beta$ karoten dan karakterisasi mutunya. [Skripsi]. Bogor: Institut Pertanian Bogor.

Jamin, F. F., \& Flores, R. A. (1998). Effect of additional separation and grinding on the chemical and physical properties of selected corn dry-milled streams. Cereal Chemistry, 75(1), 166170.

https://doi.org/10.1094/CCHEM.1998. 75.1 .166

Jung, S. Y., \& Bing, D. J. (2015). Quality characteristics of chiffon cake made with loquat fruits (Eriobotrya japonica) powder. Korean Journal of Food and Cookery Science, 31(2), 144-152.

Kadam, D. M., Wilson, R. A., \& Kaur, S. (2010). Determination of biochemical properties of foam-mat dried mango powder. International Journal of Food Science and Technology, 45(8), 16261632. https://doi.org/10.1111/j.13652621.2010.02308.x

Kandasamy, P., Varadharaju, N., Dhakre, D. S., \& Smritikana, S. (2019). Assessment of physicochemical and sensory characteristics of foam-mat dried papaya fruit powder. International Food Research Journal, 26(3), 819-829.

Mulyani, T., Yulistiani, R., \& Nopriyanti, M. (2014). Pembuatan bubuk sari buah 
markisa dengan metode foam-mat drying. Jurnal Rekapangan, 8(1), 2238.

Noordia, A., Mustar, Y. S., \& Kusnanik, N. W. (2020). Foam mat drying of banana juice: varieties of ripe banana analysis and egg albumen foam. Food Science and Technology, 40(2), 465-468. https://doi.org/10.1590/fst.24918

Pangaribuan, S., Nuryawati, T., \& Suprapto, A. (2016). Sifat fisik dan mekanik serta pengaruh penyosohan terhadap sifat fisik dan mekanik biji sorgum varietas kd 4. Prosiding Seminar Nasional Pengembangan Teknologi Pertanian. Lampung: Politeknik Negeri Lampung.

Pi, T. H., Shiau, C. Y., Chang, C. J., \& Sung, W. C. (2017). Studies on the development and quality of fish chiffon cake and its storage stability. Journal of Aquatic Food Product Technology, 26(8), 969-978. https://doi.org/10.1080/10498850.2017 .1364820

Prakotmak, P., Soponronnarit, S., \& Prachayawarakorn, S. (2010). Modelling of moisture diffusion in pores of banana foam mat using a 2-D stochastic pore network: Determination of moisture diffusion coefficient during adsorption process. Journal of Food Engineering, 96(1), 119-126. https://doi.org/10.1016/j.jfoodeng.2009 .07 .004

Priastuti, R. C., Tamrin, \& Suhandy, D. (2016). Effect of Direction and Thickness of Physical Slice. Jurnal Teknik Pertanian Lampung, 5(2), 101108.

Purbasari, D. (2019). Aplikasi metode foammat drying dalam pembuatan bubuk susu kedelai instan. Jurnal Agroteknologi, 13(1), 52-61. https://doi.org/10.19184/jagt.v13i01.9253

Segundo, C., Román, L., Lobo, M., Martinez, M. M., \& Gómez, M. (2017). Ripe banana flour as a source of antioxidants in layer and sponge cakes. Plant Foods for Human Nutrition, 72(4), 365-371. https://doi.org/10.1007/s11130-0170630-5

Shahir, S., \& Visvanathan, R. (2014). Changes in colour value of banana var. grand naine during ripening. Bioscience Trends, 7(9), 726-728.

Susanti, Y. I., \& Putri, W. D. R. (2014). Pembuatan minuman serbuk markisa merah (Passiflora edulis f. edulis Sims): kajian konsentrasi tween 80 dan suhu pengeringan. Jurnal Pangan Dan Agroindustri, 2(3), 170-179.

Wilson, R. A., Kadam, D. M., Chadha, S., \& Sharma, M. (2012). Foam mat drying characteristics of mango pulp. International Journal of Food Science and Nutrition Engineering, 2(4), 6369.

https://doi.org/10.5923/j.food.2012020 4.03

Yunieta, M., \& Sutrisno, A. (2018). Penggunaan pasta ubi kayu (Manihot esculenta Crantz) sebagai bahan baku pembuatan cake (kajian teknik pembuatan cake dan jenis lemak). Jurnal Pangan Dan Agroindustri, 6(2), $1-12$.

Zhou, W. (2014). Bakery products science and technology. Oxford: John Wiley \& Sons. 